Volume 2 Issue 2, July-December 2021: pp. 125-136.

Indonesia Private Law Review.

Fakultas Hukum, Universitas Lampung,

Bandar Lampung, Indonesia.

P-ISSN: 2723-259X E-ISSN: 2745-9284

https://jurnal.fh.unila.ac.id/index.php/iplr

\title{
ESTABLISHMENT OF A SOVEREIGN WEALTH FUND THROUGH INVESTMENT MANAGEMENT INSTITUTION IN REALISING OPTIMISATION OF FOREIGN INVESTMENT
}

\author{
Muhammad Trianda Kusuma ${ }^{1}$, Tariq Hidayat Pangestu ${ }^{2}$, Ricky Raytona ${ }^{3}$ \\ ${ }^{1}$ Universitas Gadjah Mada, Indonesia, muhammadtriandakusuma@mail.ugm.ac.id \\ ${ }^{2}$ Universitas Gadjah Mada, Indonesia, tariqhidayat99@mail.ugm.ac.id \\ ${ }^{3}$ Universitas Gadjah Mada, Indonesia, rickyraytona@mail.ugm.ac.id
}

Submitted: May 8, 2021; Reviewed:November 9, 2021; Accepted: November 11, 2021

DOI: 10.25041/iplr.v2i2.2376

\begin{abstract}
Investment can encourage the acceleration of a country's development. Foreign investment improve country's economy either with partial or complete control by the asset owner or depending on international agreements used in determining the scope of investment. However, several factors hinder the entry of foreign investment in Indonesia. To overcome this, government with parliament through Law Number 11 of 2020 concerning Job Creation emphasise the legal politics of forming a quo laworiented towards improving the investment climate in Indonesia, one of which is the establishment of the Indonesian Sovereign Wealth Fund (SWF) under the name Investment Management Institution or Lembaga Pengelola Investasi (LPI). The purpose of this study is to see how the government's political will in attracting foreign investment is through the establishment of Law Number 11 of 2020 concerning Job Creation and the legitimacy of using the SWF model in the Investment Management Institute (LPI). This research uses a combination of juridical-normative and comparative case study methods. The juridical-normative method is carried out by identifying library materials. Through the comparative case study method, the research will analyse the formation and concept of SWF in India and Russia. This study found that, the LPI plays a vital role in infrastructure financing on national strategic projects and can encourage increasing national foreign exchange. Also, the exact source of institutional funds originates from foreign investors as in the Indian and Russian state mechanisms.
\end{abstract}

Keywords: Indonesia Investment Authority, Investment, Sovereign Wealth Fund, National Strategic Project, Comparison.

\section{A. Introduction}

One of the goals of the Indonesia, as stated in the fourth paragraph of the 1945 Constitution of the Republic of Indonesia, is to promote public welfare. This constitution's goal is for Indonesia to achieve the welfare of the people. ${ }^{1}$ One of the driving factors for development is responsible economic growth, and to achieve this, it can be encouraged by investment or investment, both domestically and abroad. In the context of Indonesia as a developing country, the entry of foreign investment must be encouraged as optimally as possible to

\footnotetext{
${ }^{1}$ Azhary Azhary, Negara Hukum Indonesia: Analisis Yuridis-Normatif Tentang Unsur-Unsurnya (Jakarta: UI Press, 1995):116.
} 
achieve comprehensive development. This can be realised by carrying out development in all sectors of the nation and state.

According to Sornarajah, foreign investment transfers assets, both tangible and intangible, from one country to another to improve the economy either with partial or complete control by the asset pending on international agreements used in determining the scope of investment. ${ }^{2}$ However, in practice, several factors hinder the entry of foreign investment in Indonesia, including the many overlapping regulations, labour quality and productivity, corruption, and the lack of investment incentives. ${ }^{3}$ To overcome this, one of the steps taken by the government is related to structuring regulations as part of the legal reform agenda for volume II. ${ }^{4}$ In this context, together with the DPR, establishing Law Number 11 of 2020 concerning Job Creation using the omnibus method.

Omnibus forms laws and regulations by uniting various cross-sectors in various regulations into one product of legislation. ${ }^{5}$ The legal politics of Law Number 11 of 2020 concerning Job Creation to optimise foreign investment can also be seen in its content, one of which is forming a new Institution, namely the Investment Management Institute as Indonesia's Sovereign Wealth Fund (SWF). Though difficult to define in precise terms, SWFs are government-owned investment funds operating in private financial markets. ${ }^{6}$ SWF is generally defined as a special Investment fund created or owned by the government to control investment assets for long-term purposes. As large foreign institutional investors, SWFs act as intermediaries, transferring to host countries a variety of environmental, social, and corporate governance (ESG) practices that are consistent with their national values. ${ }^{7}$ This method has been used to attract foreign investment in various countries, including Vietnam and the Philippines, as a regulatory simplification tool.

Sovereign wealth funds have emerged as major investors in corporate and real resources worldwide. ${ }^{8}$ The formation of the SWF has pros and cons in the community. According to Faisal Basri, the formation of SWF Indonesia is a considerable risk because the primary source of funds comes from foreign investors, which is different from the SWF, which is generally used in the world where the source of funds comes from surplus state revenues. ${ }^{9}$ However, the pro community stated that the argument that requires SWF in Indonesia to use funds derived from a surplus of natural resources is not appropriate to be accepted absolutely. The reasons put forward were, among others, the inaccurate time analysis that required the management of immense natural resources, limited human resources and technology. Also, not all countries implemented a quo mechanism. ${ }^{10}$

\footnotetext{
${ }^{2}$ M. Sornarajah, The International Law on Foreign Investment, 3rd ed. (Cambridge University Press, 2012): 7 , https://doi.org/10.1017/CBO9780511841439.

3 Indonesia Investment Coordinating Board, "Regulasi Dan Deregulasi Perizinan Dalam Mendukung Peningkatan Investasi” (Jakarta, 2017), https://nslic.or.id/download/regulasi-dan-deregulasi-perizinan-dalammendukung-peningkatan-investasi/.

4 Akbar Bhayu Tamtomo, "INFOGRAFIK: Mengenal Istilah Omnibus Law," Kompas.com, 2020, https://www.kompas.com/tren/read/2020/01/21/180500665/infografik--mengenal-istilah-omnibus-law.

${ }^{5}$ Henry Campbell Black, Black's Law Dictionary, 11th ed. (New York: Thomson Reuters, 2019).

6 Ashby Monk, "Recasting the Sovereign Wealth Fund Debate: Trust, Legitimacy, and Governance," New Political Economy 14, no. 4 (2009): 451-68, https://doi.org/10.1080/13563460903287280.

7 Gurneeta Vasudeva, Lilac Nachum, and Gui Say, "A Signaling Theory of Institutional Activism: How Norway's Sovereign Wealth Fund Investments Affect Firms' Foreign Acquisitions," Academy of Management Journal 61, no. 4 (2017): 3, https://doi.org/10.5465/amj.2015.1141.

${ }^{8}$ Shai Bernstein, Josh Lerner, and Antoinette Schoar, "The Investment Strategies of Sovereign Wealth Funds," Journal of Economic Perspectives 27, no. 2 (2013): 219-38, https://doi.org/10.1257/jep.27.2.219.

9 "Faisal Basri: Rencana Pembentukan SWF RI Berisiko Tinggi," CNBC Indonesia (Indonesia: CNBC Indonesia, 2020), https://www.cnbcindonesia.com/market/20201012145146-19-193695/faisal-basri-rencanapembentukan-swf-ri-berisiko-tinggi.

${ }^{10}$ Fajar Himawan, "Sovereign Wealth Fund's Role to Catalyse Sustainable Development" (Indonesian Student Association for International Studies Webinar, 2021).
} 
SWF owned by India and Russia supports this pro-community statement. These SWFs are similar to Indonesia in using sources of funds that are not through a state surplus like the SWF concept in general, but by using injections of funds originating from the state and seeking funds from Foreign Capital investment. Based on this, the author will analyse how the formation of SWF in attracting foreign investors to come to Indonesia and how the effect by referring to state practices comparatively in other countries using the SWF model as applied in Indonesia.

The purpose of this study is to see how the government's political will in attracting foreign investment is through the establishment of Law Number 11 of 2020 concerning Job Creation and the legitimacy of using the SWF model in the Investment Management Institute or Lembaga Pengelola Investasi (LPI). This research uses a combination of juridicalnormative and comparative case study methods. The juridical-normative method is carried out by identifying library materials. The approach in this study uses a descriptive conceptual and comparative approach. Through the comparative case study method, we will analyse the formation and concept of SWF in India and Russia. This study uses several approaches, namely the statutory, conceptual, and comparative approaches. The research materials used are primary legal materials, secondary legal materials, and tertiary legal materials. Primary legal materials are binding on everyone because the competent authority makes them. Secondary legal materials or legal materials that explain primary legal materials. ${ }^{11}$ Finally, tertiary legal materials or, in this case, legal materials that provide instructions or explanations of primary and secondary legal materials. This includes books, journals, articles, papers, and seminar results. In this case, the researcher used in this study is the Black's Law Dictionary.

\section{B. Discussion}

\section{Establishment of Law Number 11 of 2020 concerning Job Creation in Encouraging Investment}

Various problems that significantly impact the continuity of investment occur in the development of investment in Indonesia, ranging from infrastructure issues to a variety of other impediments that enliven the investment climate in Indonesia. ${ }^{12}$ Investment is a strategic step in realising the country's goals. Investment can encourage the acceleration of a country's development. In particular, foreign investment significantly impacts Indonesia because it can cover the current account deficit. ${ }^{13}$ In reality, there are various obstacles to investment activities in Indonesia. These obstacles are related to laws and regulations that are not harmonious. One of the causes is many regulations, both at the central and regional levels. ${ }^{14}$ There are 61,305 legal products at the central level and 201,149 at the regional level. In other sources, it is stated that there are 1700 legal products in the form of laws, 4667 government regulations, 2166 presidential regulations, 15,672 ministerial regulations, 4138 LPNK regulations, and 15,982 regional regulations. ${ }^{15}$ According to Jimly Asshiddiqie, this situation gives a significant conclusion that the quantity of regulation, in this case, the laws and regulations in Indonesia, is obese and trapped in a hyper-regulated society. ${ }^{16}$ The large

\footnotetext{
${ }^{11}$ Peter Mahmud Marzuki, Penelitian Hukum (Jakarta: Prenada Media Group, 2014): 52.

12 Suradiyanto Suradiyanto, "The Investment Law Development to Increase Investment in Indonesia," International Journal of Law and Management 61, no. 1 (2019): 17-23, https://doi.org/10.1108/IJLMA-112017-0270.

${ }^{13}$ Rizal Irvan Amin, “Omnibus Law Antara Desiderata Dan Realita,” Jurnal Hukum Samudra Keadilan 15, no. 2 (2020): 201, https://doi.org/10.33059/jhsk.v15i2.2729.

${ }^{14}$ Rahayu Hartini, “Analisis Yuridis UU No. 25 Tahun 2007 Tentang Penanaman Modal,” Sistem Perencanaan Pembangunan Nasional IV, no. 25 (2007): 53, https://media.neliti.com/media/publications/11417-ID-analisisyuridis-uu-no-25-tahun-2007-tentang-penanaman-modal.pdf.

${ }^{15}$ Kementerian Hukum dan HAM RI, "Beranda," peraturan.go.id, accessed May 6, 2021, https://peraturan.go.id/.

${ }^{16}$ Jimly Asshiddiqie, Omnibus Law Dan Penerapannya Di Indonesia (Jakarta: Konstitusi Press, 2020).
} 
quantity of this legislation also affects the quality of the regulation. In this case, the possibility of disharmony such as overlapping and conflicts between regulations. ${ }^{17}$ The actual evidence is that the Indonesian regulatory quality index is classified as poor, with only a score of -0.07 on a scale of -2.5 to d. 2.5 even since 1996-2018, the Indonesian regulatory quality index has never moved from a minus value. ${ }^{18}$ The government and the DPR formed Law Number 11 of 2020 concerning Job Creation with the omnibus method to overcome these problems.

The omnibus method effectively overcomes the existing problems in harmonisation and simplification of regulations. The omnibus law is considered more efficient in solving many of the community's legal needs and facilitating efforts to harmonise the many regulations in Indonesia because it will be integrated into one new regulation. Furthermore, using this mechanism can increase the speed of drafting a law because, in this case, it can simultaneously correct other laws that are considered problematic. ${ }^{19}$ Using the omnibus method becomes urgent in providing practical solutions to overcome hyper-regulation. This is normal because the status quo is an obstacle for foreign investment to enter Indonesia.

Comparatively, the use of the omnibus method to encourage the entry of foreign investment has been applied in various countries. For example, the Philippines has applied this method to regulate regulations in the investment sector by issuing the Omnibus Investment Code of 1987. Through this regulation, the regulation on investment will focus on one law. ${ }^{20}$ In addition, Vietnam, funded by the World Bank, has effectively addressed its hyper-regulation problem by reviewing many laws and regulations and subsequently making them into a regulatory product capable of overcoming the difficulty of foreign investment entering the country. This is one of the critical factors for Vietnam to become a reference for foreign investors to invest. ${ }^{21}$ The quo practice is a concrete example that can be applied in Indonesia to encourage investment.

The formal formation of Law Number 11 of 2020 concerning Job Creation resulted in the simplification of disharmony regulations. Furthermore, materially various provisions emphasise the legal politics of forming a quo law-oriented towards improving the investment climate in Indonesia, one of which is the establishment of the Indonesian Sovereign Wealth Fund (SWF) under the name Investment Management Institution. In principle, the application of SWF in a country is not a new thing. SWF is one of the actors in state-controlled investment and was massively formed after the 2008 economic crisis. Furthermore, materially various provisions emphasise the legal politics of forming a quo law-oriented towards improving the investment climate in Indonesia, one of which is the establishment of the Indonesian Sovereign Wealth Fund (SWF) under the name Investment Management Institution. In principle, the application of SWF in a country is not a new thing. Consequently, SWF is one of the actors in state-controlled investment and was massively formed after the 2008 economic crisis. SWFs are born from countries with a fiscal and/or current accounts

\footnotetext{
17 Wicipto Setiadi, "Simplifikasi Peraturan Perundang-Undangan Dalam Rangka Mendukung Kemudahan Berusaha," Jurnal Rechts Vinding: Media Pembinaan Hukum Nasional 7, no. 3 (2018): 321-34, https://doi.org/10.33331/rechtsvinding.v7i3.288.

18 "Indonesia: Regulatory Quality," The Global Economy, 2021, https://www.theglobaleconomy.com/Indonesia/wb_regulatory_quality/.

19 Ahmad Redi, Omnibus law Gasasan Pengaturan untuk Kemakmuran Rakyat, Bahan Presentasi Diskusi Kolegium Jurist Institute, Rambu-Rambu Konstitusi dalam Wacana Omnibus law, Jakarta 5 Maret 2020, pg. 14.

${ }^{20}$ Vincent Suriadinata, "Penyusunan Undang-Undang Di Bidang Investasi: Kajian Pembentukan Omnibus Law Di Indonesia," Refleksi Hukum: Jurnal Ilmu Hukum 4, no. 1 (2019): 115-32, https://doi.org/10.24246/jrh.2019.v4.i1.p115-132.

21 Tirta Widi Gilang Citradi, "Pak Jokowi, Ini Penyebab Investor Pilih Vietnam Dibanding RI," CNBC Indonesia, 2019, https://www.cnbcindonesia.com/news/20190905105249-4-97273/pak-jokowi-ini-penyebabinvestor-pilih-vietnam-dibanding-ri.
} 
surplus. ${ }^{22}$ If the country already has a reliable surplus in certain countries, an SWF will be established to manage the surplus. For example, the SWF is based on the Norwegian Oil Fund (NOF), whose source of funds comes from the country's oil and gas surplus. In addition, like the SWF in the State of Kuwait, the so-called Kuwait Investment Authority aims to invest the surplus income from its oil. However, Indonesia has rarely experienced a fiscal or current account surplus in the last twenty years. However, Indonesia has rarely experienced a fiscal or current account surplus in the last twenty years. ${ }^{23}$ The purpose of establishing an Investment Management Agency Based on Article 165 of the Law a quo jo. Article 5 of Government Regulation Number 74 of 2020 concerning Investment Management Institutions is intended to increase and optimize the long term value of asset to support sustainable development.

\section{The Role of Investment Management Institutions (LPI) as Financing in National Strategic Projects and State Foreign Exchange Reserves}

Like sustainable development, infrastructure is a driving wheel for a country's economic growth or a locomotive for national and regional development. ${ }^{24}$ Through a macroeconomic approach, the availability of infrastructure services will affect the marginal productivity of private capital. In contrast, using a microeconomic approach will reduce production costs. ${ }^{25}$ This was accommodated in line with the establishment of the Indonesia Investment Authority (INA) or Lembaga Pengelola Investasi (LPI) as the urgency of the need for timely infrastructure financing and was encouraged by the National Strategic Project or Proyek Strategies National (PSN). ${ }^{26}$ Presidential Regulation Number 109 of 2020 concerning the Third Amendment to Presidential Regulation Number 3 of 2016 concerning the Acceleration of Implementation of National Strategic Projects regarding Indonesian economic progress. The government decided as many as 201 projects and 10 programs covering 23 sectors with a total value of an investment of Rp 464.6 trillion was proposed by PSN, which has passed consideration of all aspects and uses various criteria. PSN itself is a project or program implemented by the government, regional government, and business entity that has a strategic nature to increase growth and equitable development in improving community welfare and regional development. ${ }^{27}$ Previously, through Presidential Regulation Number 102 of 2016 concerning Funding for Land Acquisition for Development for the public interest in the context of implementing PSN, there was an innovation in the payment mechanism, namely through bailouts by investors or through the Public Service Agency of the State Asset Management Agency or Badan Layanan Umum Lembaga Manajemen Aset Negara (BLU LMAN). ${ }^{28}$

However, a quo mechanism often has obstacles in the repayment process by LMAN so that it has an impact on the amount of money paid back to the Business Entity. The source of

\footnotetext{
${ }^{22}$ Doddy Ariefianto, "Harapan Pada Lembaga Pengelola Investasi: Beberapa Catatan,” CNBC Indonesia, 2021, https://www.cnbcindonesia.com/opini/20210301165826-14-226999/harapan-pada-lembaga-pengelola-investasibeberapa-catatan.

${ }^{23}$ Elucidation of Government Regulation Number 74 of 2020 concerning Investment Management Institutions.

24 Abdul Haris, "Pengaruh Penatagunaan Tanah Terhadap Keberhasilan Pembangunan Infrastruktur Dan Ekonomi," Bappenas, $\quad 2009, \quad 1-9$, https://bappenas.go.id/files/3013/5228/3483/05abdul_20091014131228_2260_0.pdf.

${ }^{25}$ Ibid, pg. 1

26 Wihana Kirana Jaya, "SWF Dan Investasi Infrastruktur Nasional," Bisnis.com, 2021, https://ekonomi.bisnis.com/read/20210219/9/1358314/swf-dan-investasi-infrastruktur-nasional.

27 Article 1 number 1 Presidential Regulation Number 109 of 2020 concerning the Third Amendment to Presidential Regulation Number 3 of 2016 concerning the acceleration of the implementation of National Strategic Projects.

${ }^{28}$ Alfred Nobel and Nabila Putri Larasati, "Inovasi Pembiayaan Tanah Untuk Proyek Jalan Tol Yang Termasuk Dalam Proyek Strategis Nasional Dengan Mempergunakan Mekanisme Dana Talangan,” Jurnal HPJI 3, no. 2 (2017): 139-48, https://doi.org/10.26593/jh.v3i2.2741.\%25p.
} 
financing, especially in PSN, is not always through debt or financing that hinders the infrastructure development process. The government intends the presence of LPI as an innovative source of financing. This cannot be separated from LPI, which is more about equity participation. ${ }^{29}$ The LPI mechanism originating from foreign investment can be accepted as a general view that it is an economic instrument that will encourage development and progress. ${ }^{30}$

Meanwhile, the country's foreign exchange reserves are a crucial monetary indicator to show the strength or weakness of the fundamental condition of a nation's economy. ${ }^{31}$ As of January 2021, Bank Indonesia itself recorded an increase in the country's foreign exchange reserves to reach US\$138.0 billion, compared to the end of December, which touched US\$ 135.9 billion. ${ }^{32}$ The large inflow of foreign and financial capital and a stable exchange rate are the supporting factors for future foreign exchange reserves. Meanwhile, the main factor causing the return of foreign capital is good fiscal risk management. It cannot be separated from the implementing regulations of Law No. 11 of 2020 concerning Job Creation, including the formation of LPI, which will strengthen the inflow of foreign direct investment/Foreign Direct Investment (FDI). In attracting FDI, the government's role is needed, including creating a good investment environment, because basically, a conducive investment climate will attract the attention of foreign investors. ${ }^{33}$ Indonesia has long been a popular FDI destination in Southeast Asia, thanks to its plentiful natural resources, ample labour supply, and developing domestic market, providing multinational corporations with numerous chances for internalization when picking an overseas manufacturing location. ${ }^{34} \mathrm{FDI}$ itself is an essential or superior mechanism in explaining the continuity of national economic development compared to indirect foreign investment in a portfolio. FDI itself is an intangible investment asset. Therefore, it is done so that the company still has a control function over the investments made. ${ }^{35}$ After obtaining funds from foreign investors, LAMPU will increase and optimise the value of investments that are managed in the long term to support sustainable development. ${ }^{36}$

\section{FPI's Role in Attracting Foreign Investors to Come To Indonesia \\ a. Government's strategy to use LPI in Attracting Foreign Investors to Indonesia}

LPI Supervisory Board Cyril stated that Indonesia has great potential as a surplus investor country through considerable population growth where the immense market potential attracts foreign investors to Indonesia. Furthermore, the strategy of attracting foreign investors can be carried out with one of LPI's powers by partnering with trusted parties, such as the Indonesian

\footnotetext{
29 Dwi Aditiya Putra, “LPI Jadi Opsi Skema Pembiayaan Infrastruktur Baru Di Tanah Air,” Liputan 6, 2021, https://www.liputan6.com/bisnis/read/4503174/lpi-jadi-opsi-skema-pembiayaan-infrastruktur-baru-di-tanah-air.

${ }^{30}$ Kusnowibowo, Hukum Investasi Internasional (Bandung: Pustaka Reka Cipta, 2019).

31 Pundy Sayoga and Syamsurijal Tan, "Analisis Cadangan Devisa Indonesia Dan Faktor-Faktor Yang Mempengaruhinya," Jurnal Paradigma Ekonomika 12, no. 1 (2017): 2085-1960, https://doi.org/10.22437/paradigma.v12i1.3931.

32 Bidara Pink and Tendi Mahadi, "Cadangan Devisa Januari 2021 Tambun, Ini Kata Ekonom Bank Mandiri," Kontan.co.id, 2021, https://nasional.kontan.co.id/news/cadangan-devisa-januari-2021-tambun-ini-kata-ekonombank-mandiri.

${ }^{33}$ Dinda Amelia and I Wayan Sukadana, “Analisis Korelasi Kualitas Pemerintah Dan Foreign Direct Investment Di Lima Negara ASEAN Studi Tahun 2008-2017," Ekonomi Pembangunan Universitas Udayana 8, no. 8 (2019): 1915-46, https://ojs.unud.ac.id/index.php/eep/article/view/48978.

34 J. Thomas Lindblad, "Foreign Direct Investment in Indonesia: Fifty Years of Discourse," Bulletin of Indonesian Economic Studies 51, no. 2 (2015): 217-37, https://doi.org/10.1080/00074918.2015.1061913.

35 Valentinez Hemanona Suharyono, "Analisis Pengaruh Foreign Direct Investment Terhadap Country Advantages Indonesia (Studi Terhadap FDI Amerika Serikat Di Indonesia),” Jurnal Administrasi Bisnis (JAB) 52, no. 1 (2017): 17-18.

${ }^{36}$ Article 5 Government Regulation Number 74 of 2020 concerning Investment Management Institutions
} 
government who also invests. ${ }^{37}$ As an illustration, from $100 \%$ investment funds, if foreign investors invest $65-70 \%$, domestic investors will invest $10 \%$, and the remaining $20 \%$ from the government.

This is also following the authority of LPI, which is explained in Article 7 paragraph (2) of Government Regulation Number 74 of 2020, namely LPI can cooperate with investment partners, investment managers, BUMN, government agencies or institutions, and other entities either in domestic and foreign. Thus, when $100 \%$ of the investment funds have gone to the investment destination assets, the form is the joint capital of these entities, foreign, local, and government investors. Another strategy to attract foreign investors, according to Sri Mulyani as Minister of Finance, is by the government in terms of investing funds of Rp. 15 trillion in 2020, which Rp will increase. 75 trillion in 2021. The capital was allocated in the state budget in 2020 to establish Government Regulation No. 74 of 2020. In addition, LPI's capital will be provided in state assets, such as assets from SOEs that will cooperate with foreign investor partners. This will be very influential in attracting foreign investors because SOE assets in LPI will attract foreign funds to enter as equity, not as debt.

In addition, according to the Deputy for Investment Climate Development of the Investment Coordinating Board (BKPM), Yuliot, and following the explanation of Government Regulation no. 74 of 2020, LPI focuses on offering potential investments that provide reliable partners. These partners come from the government, BUMN, and local investors because significant investments usually require reliable domestic investors with sufficient capital. ${ }^{38}$ Therefore, LPI Indonesia leans to public-private partnership projects and private partnerships, which are collaborative engagements between government agencies and private sector companies that can finance, develop, and implement projects, such as public transportation networks and parks and convention centres. ${ }^{39}$ This is an embodiment of the strategy to attract foreign investors, which can be done with one of the LPI's powers by partnering with trusted parties to gain the trust of foreign investors.

\section{b. Comparison of LPI with SWF in India and Russia in Attracting Foreign Investors 1) Indonesian Management Agency}

In addition, Indonesia's Ministry of Finance explained that Indonesia's LPI has similarities with the SWF institution in India, namely the National Investment and Infrastructure Fund of NIIF. Moreover, NIIF has assets originating from India and attracts funds from abroad or foreign investment and not from foreign sources of surplus. ${ }^{40}$ This becomes common if contextualised in developing countries that require foreign investment in economic development and growth. In addition, the form of LPI also has similarities with Russia's SWF, namely the Russian Direct Investment Fund (RDIF), where the assets come from a combination of raising funds from the Russian state itself and attracting funds from abroad to be invested in Russia. ${ }^{41}$ The author will compare LPI with NIIF and RDIF because of the similarity of the types of SWF in terms of SWF funding that comes from raising capital from

\footnotetext{
37 Azka, Rinaldi Mohammad, Begini Cara SWF Indonesia Gaet Investasi Asing, https://ekonomi.bisnis.com/read/20210304/9/1363952/begini-cara-swf-indonesia-gaet-investor-asing, (2021), Accessed on 7 May 2021.

${ }^{38}$ See Elucidation of Government Regulation Number 74 of 2020.

${ }^{39}$ Graeme A. Hodge and Carsten Greve, "Public-Private Partnerships: An International Performance Review," Public Administration Review 67, no. 3 (2007): 545-58, https://doi.org/10.1111/j.1540-6210.2007.00736.x.

40 Caesar Akbar, Jelaskan Beda SWF di Berbagai Negara, Sri Mulyani: Indonesia Mirip India, https://bisnis.tempo.co/read/1426478/jelaskan-beda-swf-di-berbagai-negara-sri-mulyani-indonesia-miripindia,(2021), accessed on 8 May 2021.

${ }^{41}$ Trio Hamdani, Bentuk Lembaga Dana Abadi, RI Berguru ke Rusia,

https://finance.detik.com/berita-ekonomi-bisnis/d-5278152/bentuk-lembaga-dana-abadi-ri-berguru-ke-rusia.
} 
state funding. The comparison grows from attracting funds from abroad or foreign investment to see how the role of SWF in this form is to can attract foreign investors.

\section{2) National Investment and Infrastructure Fund (NIIF) in India}

NIIF is an SWF originating from India that focuses on investment funding, especially in road infrastructure, ports, airports, and many more. ${ }^{42}$ India's NIIF has a different concept from the SWF, which manages the fiscal surplus or current account. SWF India is oriented towards obtaining funds from foreign investment and funding by the Indian government. ${ }^{43}$ The use of foreign investment funds is based on the ratio of the difficulty for the Indian government in establishing an SWF with a funding model from a state surplus fund where the Indian government prioritises surplus funds for other social interests. ${ }^{44}$

NIIF's primary strategy in attracting foreign investors is supported by India's Minister of Finance, who stated that the Indian government strongly supports the implementation of NIIF in India. The Indian government provides 100\% tax-free interest income, dividends, and capital gains related to investments through NIIF. In infrastructure and other sectors notified before 31 March 2024 and with a lock-in period of at least 3 years. ${ }^{45}$ On the one hand, this incentive is intended to make NIIF's operations run effectively and, on the other hand, to attract foreign investors to invest their funds in India.

The tangible results of the policy can be seen in October 2017 NIIF successfully signed the first $\$ 1$ billion investment agreement and cooperation with the Abu Dhabi Investment Authority (ADIA). ${ }^{46}$ Following this partnership agreement, ADIA became the first international institutional investor in the Master Fund from NIIF, an infrastructure fund with the primary objective of investing in operating assets in core infrastructure sectors such as roads, ports, airports, electricity, and many more ${ }^{47}$ Shareholders in National Investment and Infrastructure Fund Ltd, together with the Government of India, make up 49\% of shareholders. ${ }^{48}$ Domestic Institutional Investors (DI) such as the HDFC group, ICICI Bank, Kotak Mahindra Life and Axis bank are also contributors to the NIIF Master Fund. ${ }^{49}$ Further in June 2018, the Asian Infrastructure Investment Bank announced a \$200 million investment

\footnotetext{
${ }^{42}$ Economic Times, https://economictimes.indiatimes.com/news/economy/infrastructure/budget-2020-taxexemption-for-sovereign-funds-to-boost-india-infra-play/articleshow/73839614.cms. accessed on 7 May 2021

${ }^{43}$ Bryan J. Balin, "Sovereign Wealth Funds: A Critical Analysis," SSRN Electronic Journal 41, no. 2 (2011): 25-47, https://doi.org/10.2139/ssrn.1477725.

${ }^{44}$ Diva Rai, 2020, Will India's love affair with sovereign wealth funds continue,

https://blog.ipleaders.in/will-indias-love-affair-with-sovereign-wealth-funds-continue/. Accessed on 7 May 2021.

${ }^{45}$ The Economic Times, 2020, Budget 2020: Tax exemption for sovereign funds to boost India infra play

https://economictimes.indiatimes.com/news/economy/infrastructure/budget-2020-tax-exemption-for-sovereignfunds-to-boost-india-infra-play/articleshow/73839614.cms?from=mdr. Accessed on 7 May 2021.

46 The Economic Times, 2017, NIIF, ADIA sign investment agreement worth \$1 billion,

https://economictimes.indiatimes.com//news/economy/foreign-trade/niif-adia-sign-investment-agreement-worth1-billion/articleshow/61103444.cms?utm_source=contentofinterest\&utm_medium=text\&utm_campaign=cppst. NIIF, ADIA sign investment agreement worth \$1 billion". Accessed on 7 May 2021.

47 The Financial Express, 2017, NIIF plans $\$ 5$ bn master fund to oil infrastructure sector wheel, https://www.financialexpress.com/industry/niif-plans-5-bn-master-fund-to-oil-infrastructure-sectorwheel/844291/. Accessed on 7 May 2021.

48 Swaraj Singh Dhanjal, 2017, Abu Dhabi Investment Authority to invest in NIIF's Master Fund, https://www.livemint.com/Companies/YqtjRoXyALWGlo7Z5zyyXJ/Abu-Dhabi-Investment-Authority-toinvest-in-NIIFs-Master-Fu.html. Accessed on 7 May 2021.

49 Times of India, 2018, NIIF, DP World to invest up to \$3bn in ports, logistics - Times of India, https://timesofindia.indiatimes.com/business/india-business/niif-dp-world-to-invest-up-to-3bn-in-portslogistics/articleshow/62612676.cms.
} 
in the NIIF Fund..$^{50}$ AIIB board agreed to invest $\$ 100$ million at this point and $\$ 100$ million later. ${ }^{51}$ In February 2021, the NDB (New Development Bank) announced a \$100 million investment in the NIIF Fund. Moreover, in February 2018, the Master Fund created its first platform with DP World to invest in India's ports and logistics sector. ${ }^{52}$ Together, NIIF and DP World announced a $\$ 3$ billion investment in the platform. ${ }^{53}$ It can be seen that these funds constitute a reasonably large accumulation which can then be directed towards achieving development both sectorally and comprehensively in the long term. In addition, this condition indicates that although the form of NIIF itself is not a form of SWF in general, such as the big countries of Norway, Singapore, Kuwait, and so on. NIIF succeeded in attracting foreign investors and cooperated with a vast investment value.

\section{3) Russian Direct Investment Fund (RDIF)}

Russia has 3 types of SWF. The first form is the Stabilization Fund of Russia, further divided into two forms: the Russia Reserve Fund and the Russia National Welfare Fund in early $2018 .^{54}$ These two forms of the Russian SWF are financed by the proceeds of surplus oil revenues in Russia, which resemble the Norwegian SWF form, namely the Norwegian Sovereign Wealth Fund (NSWD). The third form is the Russian Direct Investment Fund (RDIF), a mixed model focusing on stabilisation and strategic development, which has a structure similar to holding public, private partnerships. ${ }^{55}$ RDIF The third form is the Russian Direct Investment Fund (RDIF), which is a mixed model with a focus on stabilisation as well as strategic development, which has a structure similar to that of

The effectiveness of RDIF can be seen through cooperation with China Investment Corporation (CIC) which succeeded in creating a USD 2 billion Russia-China Investment Fund. ${ }^{56}$ In addition, RDIF has also successfully collaborated with Mubadala, an investment and development company based in Abu Dhabi, to launch a $\$ 2$ billion joint investment fund. ${ }^{57}$ To pursue opportunities in Russia. The funds will mainly be focused on long-term investment projects in various industrial sectors. In addition, Mubadala manages a $\$ 5$ billion commitment from the Abu Dhabi Ministry of Finance to invest in Russian infrastructure projects. The RDIF model in co-investing with foreign investors in Russian domestic is joint ventures abroad. This model is similar to holding public, private partnerships have proven quite successful, with evidence of more than USD 10 billion in reserve funds under management,

50 Bloomberg Quint, 2018, AIIB Clears \$200 Million Infusion Into NIIF To Aid Infrastructure Growth, https://www.bloombergquint.com/business/2018/06/25/aiib-clears-200-million-infusion-into-niif-to-aidinfrastructure-growth.

${ }^{51}$ The Economic Times, 2018, AIIB to invest $\$ 200$ million into a NIIF fund of funds, https://economictimes.indiatimes.com/news/economy/finance/aiib-to-invest-200-million-into-an-niif-fund-offunds/articleshow/64720572.cms.

52 The Hindu, 2018, NIIF, DP World to invest $\$ 3$ bn, https://economictimes.indiatimes.com/news/economy/finance/aiib-to-invest-200-million-into-an-niif-fund-offunds/articleshow/64720572.cms.

${ }^{53}$ Business Standard India, NIIF's first investment: A $\$ 3$ bn fund for logistics biz with UAE's DP World, https://www.business-standard.com/article/economy-policy/niif-s-first-investment-a-3-bn-fund-for-logistics-bizwith-uae-s-dp-world-118012200421_1.html.

${ }^{54}$ Ingilab Ahmadov, Stela Tsani, and Kenan Aslanli, "Sovereign Wealth Funds as the Emerging Players in the Global Financial Arena: Characteristics, Risks and Governance," Revenue Watch Institute, 2011, 73, https://resourcegovernance.org/sites/default/files/documents/swfs-caspian-countries1.pdf.

55 Deloitte, 2012, Investment in Russia Wanted: billion-dollar funds, https://www2.deloitte.com/content/dam/Deloitte/ru/Documents/tax/dttl_investment-in-russia_12072012_en.pdf. Accessed on 8 May 2021.

56 Brian Spegele, 2011, China to Invest in Russian Fund. https://www.wsj.com/articles/SB10001424052970203499704576624542421302596 Accessed on 7 May 2021.

57 RDIF, 2013, Russian Direct Investment Fund and Mubadala establish co-investment fund, https://rdif.ru/Eng_fullNews/253/. Accessed on 8 May 2021. 
USD 40 billion raised for mutual funds and USD 1.5 trillion invested in the Russian economy until 2018. Thus, it does not become an obstacle in the form of SWF, which relies on foreign investment funds as a source of funding in a country for development.

\section{Conclusion}

Through Law No. 11 of 2020 concerning Job Creation, the government seeks to increase the potential for easy entry of foreign investment, especially foreign direct investment (Foreign Direct Investment). This includes forming Sovereign Wealth Fund (SWF), which is Lembaga Pengelola Investasi (LPI). LPI itself functions as an innovation in infrastructure financing in Proyek Strategies Nasional (PSN), replacing the "bridging fund" method by BLU LMAN. In addition, LPI can also increase the country's foreign exchange reserves due to the inflow of foreign capital flows through foreign investment.

LPI's source of funds does not use surplus natural wealth as countries that are members of the Gulf Cooperation Council, such as Kuwait in Kuwait Investment Authority and other countries. In this case, LPI's primary funding source comes from foreign investment. It has also been applied by the National Investment and Infrastructure Fund (NIIF) in India and the Russian Direct Investment Fund (RDIF) in Russia. The due entity has proven to attract foreign investment and its management for long-term development.

Based on this, the author provides the following suggestions:

1. The government needs to optimise foreign investment's entry, including the issue of deregulation at the level of legislation under the law.

2. Implementation of Good Governance in Investment Management Institutions to increase foreign investors' confidence in investing domestically in a sustainable manner.

3. LPI needs to ensure that the management of funds carried out to develop national strategic projects is right on target.

4. Disclosure of information in the distribution of foreign investment funds into infrastructure financing in the National Strategy Project to prevent corrupt practices

\section{BIBLIOGRAPHY}

Ahmadov, Ingilab, Stela Tsani, and Kenan Aslanli. "Sovereign Wealth Funds as the Emerging Players in the Global Financial Arena: Characteristics, Risks and Governance." Revenue

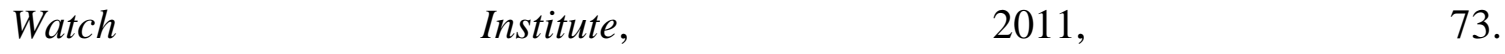
https://resourcegovernance.org/sites/default/files/documents/swfs-caspiancountries1.pdf.

Amelia, Dinda, and I Wayan Sukadana. "Analisis Korelasi Kualitas Pemerintah Dan Foreign Direct Investment Di Lima Negara ASEAN Studi Tahun 2008-2017." Ekonomi Pembangunan Universitas Udayana 8, no. 8 (2019): 1915-46. https://ojs.unud.ac.id/index.php/eep/article/view/48978.

Amin, Rizal Irvan. "Omnibus Law Antara Desiderata Dan Realita." Jurnal Hukum Samudra Keadilan 15, no. 2 (2020): 201. https://doi.org/10.33059/jhsk.v15i2.2729.

Ariefianto, Doddy. "Harapan Pada Lembaga Pengelola Investasi: Beberapa Catatan." CNBC Indonesia, 2021. https://www.cnbcindonesia.com/opini/20210301165826-14226999/harapan-pada-lembaga-pengelola-investasi-beberapa-catatan.

Asshiddiqie, Jimly. Omnibus Law Dan Penerapannya Di Indonesia. Jakarta: Konstitusi Press, 2020.

Azhary, Azhary. Negara Hukum Indonesia: Analisis Yuridis-Normatif Tentang UnsurUnsurnya. Jakarta: UI Press, 1995.

Balin, Bryan J. "Sovereign Wealth Funds: A Critical Analysis." SSRN Electronic Journal 41, 
no. 2 (2011): 25-47. https://doi.org/10.2139/ssrn.1477725.

Bernstein, Shai, Josh Lerner, and Antoinette Schoar. "The Investment Strategies of Sovereign Wealth Funds." Journal of Economic Perspectives 27, no. 2 (2013): 219-38. https://doi.org/10.1257/jep.27.2.219.

Black, Henry Campbell. Black's Law Dictionary. 11th ed. New York: Thomson Reuters, 2019.

Citradi, Tirta Widi Gilang. "Pak Jokowi, Ini Penyebab Investor Pilih Vietnam Dibanding RI." CNBC Indonesia, 2019. https://www.cnbcindonesia.com/news/20190905105249-497273/pak-jokowi-ini-penyebab-investor-pilih-vietnam-dibanding-ri.

"Faisal Basri: Rencana Pembentukan SWF RI Berisiko Tinggi." CNBC Indonesia. Indonesia: CNBC Indonesia, 2020. https://www.cnbcindonesia.com/market/20201012145146-19193695/faisal-basri-rencana-pembentukan-swf-ri-berisiko-tinggi.

Haris, Abdul. "Pengaruh Penatagunaan Tanah Terhadap Keberhasilan Pembangunan Infrastruktur Dan Ekonomi." Bappenas, 2009, 1-9. https://bappenas.go.id/files/3013/5228/3483/05abdul_20091014131228_2260_0.pdf.

Hartini, Rahayu. "Analisis Yuridis UU No. 25 Tahun 2007 Tentang Penanaman Modal." Sistem Perencanaan Pembangunan Nasional IV, no. 25 (2007): 53. https://media.neliti.com/media/publications/11417-ID-analisis-yuridis-uu-no-25-tahun2007-tentang-penanaman-modal.pdf.

Himawan, Fajar. "Sovereign Wealth Fund's Role to Catalyse Sustainable Development." 2021.

Hodge, Graeme A., and Carsten Greve. "Public-Private Partnerships: An International Performance Review." Public Administration Review 67, no. 3 (2007): 545-58. https://doi.org/10.1111/j.1540-6210.2007.00736.x.

The Global Economy. "Indonesia: Regulatory Quality," 2021. https://www.theglobaleconomy.com/Indonesia/wb_regulatory_quality/.

Indonesia Investment Coordinating Board. "Regulasi Dan Deregulasi Perizinan Dalam Mendukung Peningkatan Investasi.” Jakarta, 2017. https://nslic.or.id/download/regulasidan-deregulasi-perizinan-dalam-mendukung-peningkatan-investasi/.

Jaya, Wihana Kirana. "SWF Dan Investasi Infrastruktur Nasional." Bisnis.com, 2021. https://ekonomi.bisnis.com/read/20210219/9/1358314/swf-dan-investasi-infrastrukturnasional.

Kementerian Hukum dan HAM RI. "Beranda." peraturan.go.id. Accessed May 6, 2021. https://peraturan.go.id/.

Kusnowibowo. Hukum Investasi Internasional. Bandung: Pustaka Reka Cipta, 2019.

Lindblad, J. Thomas. "Foreign Direct Investment in Indonesia: Fifty Years of Discourse." Bulletin of Indonesian Economic Studies 51, no. 2 (2015): 217-37. https://doi.org/10.1080/00074918.2015.1061913.

Marzuki, Peter Mahmud. Penelitian Hukum. Jakarta: Prenada Media Group, 2014.

Monk, Ashby. "Recasting the Sovereign Wealth Fund Debate: Trust, Legitimacy, and Governance." New Political Economy 14, no. 4 (2009): 451-68. https://doi.org/10.1080/13563460903287280.

Nobel, Alfred, and Nabila Putri Larasati. "Inovasi Pembiayaan Tanah Untuk Proyek Jalan Tol Yang Termasuk Dalam Proyek Strategis Nasional Dengan Mempergunakan Mekanisme Dana Talangan." Jurnal HPJI 3, no. 2 (2017): 139-48. https://doi.org/10.26593/jh.v3i2.2741.\%25p.

Pink, Bidara, and Tendi Mahadi. "Cadangan Devisa Januari 2021 Tambun, Ini Kata Ekonom Bank Mandiri." Kontan.co.id, 2021. https://nasional.kontan.co.id/news/cadangan-devisajanuari-2021-tambun-ini-kata-ekonom-bank-mandiri.

Putra, Dwi Aditiya. "LPI Jadi Opsi Skema Pembiayaan Infrastruktur Baru Di Tanah Air." 
Liputan 6, 2021. https://www.liputan6.com/bisnis/read/4503174/lpi-jadi-opsi-skemapembiayaan-infrastruktur-baru-di-tanah-air.

Sayoga, Pundy, and Syamsurijal Tan. "Analisis Cadangan Devisa Indonesia Dan FaktorFaktor Yang Mempengaruhinya.” Jurnal Paradigma Ekonomika 12, no. 1 (2017): 20851960. https://doi.org/10.22437/paradigma.v12i1.3931.

Setiadi, Wicipto. "Simplifikasi Peraturan Perundang-Undangan Dalam Rangka Mendukung Kemudahan Berusaha." Jurnal Rechts Vinding: Media Pembinaan Hukum Nasional 7, no. 3 (2018): 321-34. https://doi.org/10.33331/rechtsvinding.v7i3.288.

Sornarajah, M. The International Law on Foreign Investment. 3rd ed. Cambridge University Press, 2012. https://doi.org/10.1017/CBO9780511841439.

Suharyono, Valentinez Hemanona. "Analisis Pengaruh Foreign Direct Investment Terhadap Country Advantages Indonesia (Studi Terhadap FDI Amerika Serikat Di Indonesia)." Jurnal Administrasi Bisnis (JAB) 52, no. 1 (2017): 17-18.

Suradiyanto, Suradiyanto. "The Investment Law Development to Increase Investment in Indonesia." International Journal of Law and Management 61, no. 1 (2019): 17-23. https://doi.org/10.1108/IJLMA-11-2017-0270.

Suriadinata, Vincent. "Penyusunan Undang-Undang Di Bidang Investasi: Kajian Pembentukan Omnibus Law Di Indonesia." Refleksi Hukum: Jurnal Ilmu Hukum 4, no. 1 (2019): 115-32. https://doi.org/10.24246/jrh.2019.v4.i1.p115-132.

Tamtomo, Akbar Bhayu. "INFOGRAFIK: Mengenal Istilah Omnibus Law." Kompas.com, 2020. https://www.kompas.com/tren/read/2020/01/21/180500665/infografik--mengenalistilah-omnibus-law.

Vasudeva, Gurneeta, Lilac Nachum, and Gui Say. "A Signaling Theory of Institutional Activism: How Norway's Sovereign Wealth Fund Investments Affect Firms' Foreign Acquisitions." Academy of Management Journal 61, no. 4 (2017): 3. https://doi.org/10.5465/amj.2015.1141. 